\title{
Factors Influencing Generations Y students' Attitude towards Online Shopping
}

\author{
K.M Makhitha \\ Senior Lecturer: Department of Logistics, Vaal University of Technology, South Africa \\ Email:merceym@vut.ac.za or kmakhitha@yahoo.com
}

\section{Doi:10.5901/mjss.2014.v5n21p39}

\begin{abstract}
Internet access grew exponentially in South Africa; online shopping in South Africa has also shown an upward trend, although it is still in its infancy. Generation Y consumers, and students in particular, spend more time on the internet and are regarded as the most attractive market segments for online shopping. Their spending power exceeds those of their parents. Marketers should, therefore, understand factors that determine the Generation Y students' attitude towards online shopping. A survey method, using convenience sampling, was adopted to study the attitude of Generation Y students towards online shopping. A closed-ended questionnaire was distributed among the Generation Y students at a university of technology. The outcomes of the study indicated that the majority of Generation Y students do not shop online. However, the Generation Y students spend more time on the Internet, accessing the Internet on a daily basis. The Generation $Y$ students at different age groups did not differ in attitudes towards online shopping. Generation $Y$ students were found to be influenced by the perceived convenience associated with online shopping.
\end{abstract}

Keywords: Generation Y students, online shopping, online shopping factors, shopping intention

\section{Introduction}

Online shopping is a growing phenomenon globally (Brown, Cajee, Davies \& Strobel, 2003; Kau, Tang \& Ghose, 2003), and has shown an upward trend of consumers who are shopping online (Kau et al., 2003). This observed growth has been made possible by the developments in the Internet access. According to WorldWideWorx (2012), Internet access grew from 2.6 million in 2010 to 8.2 million in 2012. In South Africa, the study further revealed that 7.9 million South Africans access the Internet on their cellphones. Of the 7.9 million that access the Internet from their cellphones, 2.48 million access it only from their cellphones and do not have access to computers. Typically, consumers use their smart phones to access the Internet and to shop online (Effective Measure, 2014).

The shopping activities conducted by consumers on the Internet are confined no longer to purchasing of books and DVDs, plane tickets and applications, but including the buying of a variety of products and services (MasterCard, cited in Business Day Live, 2014). For instance, consumers are also purchasing groceries (38\%), clothing (34\%), and personal care (20\%) brands online, and online purchases of these products have increased by 7 percent, 8 percent and 6 percent respectively, with the number of visits to these sites averaging at two per week.

Generation $Y$ consumers are the most attractive market segments and have become the new target market for advertisers and marketers as a result of their increasing buying power (Koutras, 2006). They constitute over 50 percent of the SA total population and their spending power is overtaking those of their parents and has increased over the GDP growth rate (Koutras, 2006). According to the recent Student Village's annual student spend survey, (Student Village, 2014), students spend an average of R3768 per month and a combined spend of R6.1bn and R8.4bn on technology and food and groceries respectively. Since students, as Generation $Y$ consumers, are an important market for various products, it is important for online retailers to understand their attitude towards online shopping.

Experts differ on the exact age group of Generation Y. They have been classified by several authors as consisting of individuals born between 1979 and 1994 (Cant \& Machado, 2004; Kotler, 2003; Shiffman \& Kanuk, 2007), 1986 and 2005 (Market, 2004), and comprises those between the age of 15 and 29 (Bevan-Dye, Garnet \& De Klerk, 2012. According to Statistics South Africa (2013), those in the age group 15 to 29 accounted for approximately 14968990 members, which is 28 percent of the total population in SA. They are the largest segment and consist of university students (Kinley, Josium \& Lockett, 2010).

Generation $Y$ is the first generation to grow in post-apartheid era in SA (Bevan-Dye et al., 2012) and into the age of the Internet, cellular phones, convergent technologies and multiplatform media (Alch, 2000). Members of this generation grew up in the multimedia-rich world that allows $24 / 7$ access to global news and information, virtual social networking 
such as Facebook and Twitter, and virtual social media such as YouTube (Bevan-Dye et al., 2012; Schalbe, 2009; Smith, 2012). Generation $Y$ forms part of the global youth culture that transcends all boundaries in the world and are part of the global village (Cant \& Machado, 2004). They demonstrate a general liking towards purchasing, and have ample time for shopping, with a tendency to spend money freely and quickly (Ma \& Niehm, 2006). They are determined to attain a university degree, are well educated, and have self-confidence (Broadbridge, Maxwell \& Ogden, 2007). As a result, they have potential for future earnings due to their high level of education, and have significant spending power (Cui, Trent, Sullivan \& Matiru, 2003). Their spending power makes them a significant market to both marketers and retailers (Ma \& Niehm, 2006). Furthermore, Generation Y consumers are less loyal, switch from one brand to another (Rahman \& Azhar, 2010:92), and search for bargains (Foscht, Schloffer, Malotes \& Chia, 2009).

Whilst many research papers have been published on Generation $Y$ consumers and students in particular (BevanDye et al., 2012:5582; Koutras 2006:108), there is scant research on Generation Y students' attitude towards online shopping. Existing research have focused on social media consumption, advertising credibility across media channels (Jordaan, Ehlers \& Grove, 2011), cellphone consumption Koutras 2006), materialism and status consumption (BevanDye et al., 2012), cross-cultural differences (Lynton, April \& Asluridge), shopping styles (Mandlazi, Dhurup \& Mafini, 2013), and the influence of colour (Muller, 2011).

\section{Factors Influencing Online Shopping}

Consumer attitude towards online shopping is driven by diverse factors (Brown, Pope \& Voges, 2003). Researchers have adopted the technology acceptance model (TAM) to study the factors influencing consumer attitude towards online shopping. TAM was developed initially to explain and predict user acceptance of information technology (IT) in the workplace (Davies, 1989), but has recently been used to predict consumers' attitude towards online shopping behaviour. According to Davies (1989), two factors cause consumers to accept or reject the use of IT, perceived usefulness and perceived ease of use. However, additional factors have been included to predict online shopping behaviour as researchers found that consumers are influenced by diverse factors and not only perceived usefulness and perceived ease of use which are the utilitarian factors proposed by the TAM (Vijayasarathy, 2004). Researchers believe that consumers are influenced by hedonic shopping factors (Khare, Khare \& Singh, 2012; Xu \& Paulines, 2005). The utilitarian factors are goal-oriented factors which envision that consumers consider product-related information prior to purchase while hedonic factors reflect the experience and entertainment factors of online shopping (Babin, Dardin \& Griffin, 1994). This study will investigate the utilitarian motives influencing Generation Y students' attitude towards online shopping. Students are more familiar with the Internet (Xu \& Paulines, 2005) and are more likely to shop online (Johnson, Lennon, Jasper, Damhorst \& Lakner, 2003)

Some of the most common utilitarian motivation factors influencing online shopping are perceived usefulness (Khare et al., 2012; Vijayasarathy, 2004; Davies, 1989), ease of use (Khare et al., 2012; Vijayasarathy, 2004; Davies, 1989), security and privacy (Khare et al., 2012; Ha \& Stoel, 2009; Lian \& Lin, 2008; Vijayasarathy, 2004), convenience (Jen-Hung \& Yi-Chun, 2010; Childers et al., 2001). Perceived usefulness refers to the fact that a user believes in the existence of a positive use-performance relationship while the perceived ease of use refers to the degree to which a person believes that using a particular system would be free of effort (Childers et al., 2001; Davies, 1989). Convenience refers to time savings and effort savings that include the physical and mental effort (Jen-Hung \& Yi-Chun, 2010). This is because consumers consider that online shopping makes it easy for them to locate suppliers, find items and procure offerings (Balasubramanian, 1997) without having to leave their homes (Wolfinbarger \& Gilly, 2001). Security concerns are a major drawback for online shopping intention (Mastercard, cited in Business Day Live, 2014; Wolfinbarger \& Gilly, 2003; Ranganathan \& Ganapathy, 2002). Security is defined as the extent to which consumers believe that making online purchases is secure (Vijayasarathy, 2004). It is closely related to privacy risks, which are concerned with the ease with which consumers' personal information, their browsing and shopping habits can be captured online and the possibility for the misuse of information (Vijayasarathy, 2004).

In studying the motivations for online retail shopping behaviour, Childers et al., (2001) investigated the impact of online shopping motivation factors: usefulness, ease of use and enjoyment and attitude towards online shopping. The study found positive relationships between usefulness, ease of use and enjoyment and attitude towards online shopping. In another study, Alam Bakar, Ismail and Ahsan (2008) studied the Generation Y consumer's online shopping behaviour. The study examined four factors, website design, reliability, customer service, and trust as factors that influence online shopping. Except for website design, reliability, customer service and trust were found to have an impact on consumer behaviour towards online shopping. 
Khare et al., (2012) examined the challenges and opportunities for the Indian retail sector to attract online shoppers. Part of the investigation included the factors that influence consumer behaviour towards online buying such as perceived usefulness, ease of use and perceived risk. Findings revealed that consumers are influenced by these factors when shopping online. The study also indicated that consumers differed in their online shopping attitude with respect to ease of use. Furthermore, male consumers were reported to be more likely to use the Internet for shopping than female. The latter was confirmed by Khare and Rakesh (2011) who found that males and females differ in their attitude towards online shopping.

Vijayasarathy (2004) investigated nine factors that influence consumer attitude towards online shopping. Factors included usefulness, ease of use, compatibility, privacy, security, normative beliefs and self-efficacy. The ease of use, usefulness and compatibility were reported to have a strong influence on intention to shop online. The security associated with payment methods was indicated as a major inhibitor of on-line shopping, since consumers are wary about transmitting credit card information over the Internet. The attitude towards shopping on-line was found to be strongly associated with the intention to shop-online. It is important to note that factors influencing consumer attitude towards online shopping differ for different types of products (Lian \& Lin, 2008).

In another study, Yang and Lester (2004) studied the attitudes of online and non-online student shoppers. The study investigated four positive and negative factors, consisting of 20 statements, influencing students attitude towards Internet shopping. The four factors were convenience (with eight statements measuring the factor), efficiency (five statements measuring the factor), anxiety/inconvenience (five statements measuring the factor) and effort/impersonality (four statements measuring the factor). There were two statements that appeal the most to shoppers, and three most discouraging statements. The attitudes towards online shopping were found to differ for online shoppers and non-online shoppers. Online shoppers have stronger, more positive feelings about online shopping than the non-online shoppers (Yang \& Lester, 2004).

Bigne'-Alcaniz, Ruiz-Mafe', Alda's-Manzano \& Sanz-Blas, (2008) examined the attitude of Spanish consumers who never shop online. The results indicated that ease of use affects consumer attitude towards online shopping. Shih (2004) also researched consumer attitude towards online shopping. The study reported that ease of use and perceived usefulness determine consumers' attitude towards online shopping. However, perceived usefulness was found not to affect consumer acceptance of online shopping models. Park and Kim (2003) found security concerns to affect consumer attitude towards online shopping.

\section{Rationale for the Study}

Consumers more likely to use the online shopping are those belonging to Generation $Y$ (Jordaan \& Ehlers, 2009). Studies (Seock \& Chen-Yu, 2007; Vrechopoulos, Siomkos \& Doukindis, 2001) indicate an increasing number of Generation $Y$ consumers exploring online shopping. Research has indicated that Generation $Y$ consumers shop online for more products than the older age group (Sorce, Perroti \& Widrick, 2005). One of the reasons why Generation $Y$ consumers shop online is the convenience associated with the Internet. Thus, Sorce et al., (2005) maintain that Generation $Y$ consumers believe that shopping online is more convenient. Therefore, the purpose of this study is to investigate factors that influence Generation Y students towards online shopping.

As already stated, Students are more familiar with the Internet (Xu \& Paulines, 2005) and are more likely to shop online (Johnson et al., 2003) than the older generation. Generation Y consumers were reported by Khare et al., (2012) as preferring to use the internet, since they perceive it as easy to use. Yang and Lester (2004) found that shoppers and nonshoppers possess different attitudes towards online shopping. Then and DeLong (1999) investigated Generation Y students to determine if they used the internet to shop for clothing. The investigation indicated that students consider security, convenience and return policy when shopping online, which shows that they are influenced by utilitarian motives.

H1 There are significant differences between online shoppers and non-online shoppers' attitudes towards online shopping

H2 There are significant differences between the Generation $Y$ students' frequency of Internet usage, and the attitude towards online shopping

H3 Age significantly impacts on Generation Y students' attitudes towards online shopping

\section{Research Methodology}

A survey method was deemed appropriate for this research to explore the attitude of Generation $Y$ students towards online shopping. A convenience sampling method was used. 


\subsection{Participants}

The participants for this research were the Generation Y students at a major university of technology. The study adopted a similar approach to Ramnarain and Govender (2013); Jordaan and Ehlers (2009) and Gupta, Handa \& Gupta (2008) who targeted students at universities. This research targeted students studying undergraduate and postgraduate degrees. Generation Y students were targeted since they spend more time using the Internet (Du Plessis, Mostert \& North, 2004) and are more likely to purchase online (Jordaan \& Ehlers, 2009; Sorce et al., 2005).

\subsection{Data collection and measuring Instrument}

The questionnaire was developed using the variables of prior research studies (Khare et al., 2012; Khare \& Rakesh, 2011; Vijayasarathy, 2004; Kim, 2004; Childers et al., 2001; Davies, 1989) to investigate the utilitarian factors that influence Generation Y students' attitude towards online shopping. There were eight demographic questions. The students' attitude towards online buying was measured using 20 statements addressing the utilitarian factors. Students were expected to rate each of the factors on a scale from one to five, with one indicating strongly disagree and five indicating strongly agree. Questionnaires were administered in class by lecturers teaching at different levels of study and in different departments. Students were given time to complete the questionnaire in class. They were informed that completing a questionnaire was voluntary and that they must willingly partake in the study. Over 600 questionnaires were distributed. However, only 290 questionnaires were returned. Of the 290 returned only, 256 were fully complete and usable.

\subsection{Data analysis}

The data was analysed using Statistical Package for Social Sciences (SPSS) version 22 for Windows. Various statistical analyses were conducted including the descriptive study, factor analysis, t-test, Anova and regression analysis.

\subsection{Reliability and validity}

Reliability analysis (Cronbach alpha) was computed to determine the internal consistency of the factors influencing Generation Y students' attitude towards online shopping. The Cronbach alpha for the composite scale was 0.818 . Malhotra (2010) deemed the Cronbach alpha of 0.78 as satisfactory. Since factor analysis was conducted for the factors influencing attitude towards online shopping and five factors were identified, the Cronbach alpha for each of the five factors were 0.78 (convenience), 0.77 (perceived risk), 0.82 (shopping intention), 0.73 (perceived ease of use), and 0.59 (perceived usefulness).

Content validity was also established through a pre-test of questionnaire with three academics. A pilot test was also conducted in the field with 30 students. Question wording, formatting and content were adapted after the pre-test and pilot test stages.

\section{Findings and Discussion}

\subsection{The sample composition}

The sample composition consisted of Generation $Y$ students in different age groups with majority of students in the age group $18-21(51 \%, N=132)$ followed by those between the age of $22-25$ (about $40 \%, N=102)$. The majority of respondents were females represented by 54 percent $(\mathrm{N}=140)$. Over 82 percent of the students were under-graduate.

\subsection{The general internet usage}

Table 1 shows the purpose of Internet access and whether students buy online or not. 
Table 1: General usage of Internet

\begin{tabular}{|l|c|c|}
\hline & Frequency & Percent \\
\hline Place of Internet access & & \\
\hline University & 187 & 72.8 \\
\hline Home & 59 & 23.0 \\
\hline Internet café & 53 & 20.6 \\
\hline Private access through a cellphone & 156 & 60.7 \\
\hline Purpose of internet access & & \\
\hline Education & 197 & 76.7 \\
\hline Entertainment & 138 & 53.7 \\
\hline Online shopping & 6 & 2.3 \\
\hline Communication & 141 & 54.9 \\
\hline Seeking information & 167 & 65 \\
\hline Pleasure & 74 & 29.8 \\
\hline Experience using internet & & 3.9 \\
\hline Less than 6 months & 10 & 5.1 \\
\hline Between 6 months to 1 year & 13 & 7.0 \\
\hline 1-2 years & 18 & 21.9 \\
\hline 3-4 years & 56 & 62.1 \\
\hline Over 4 years & 159 & \\
\hline Frequency of internet access & & 68.8 \\
\hline Daily & 176 & 11.3 \\
\hline 2-3 times per week & 29 & 14.5 \\
\hline More than 3 times per week & 37 & \\
\hline Occasionally & 14 & 12.1 \\
\hline Online shopping & & 87.9 \\
\hline shop online & 31 & \\
\hline Do not shop online & 226 & \\
\hline & & \\
\hline
\end{tabular}

As can be seen from the above table the majority of students access the Internet from the university as shown by 72.8 percent $(\mathrm{N}=187)$ of the students. Students also access the Internet from their cellphones. Students use the Internet for various purposes with the main purpose of Internet access being education $(76.7 \%, \mathrm{~N}=197)$ followed by seeking information (65\%, N=167) and communication (54.9\%, N=141). Over 62 percent of students have had Internet access for more than four years, which implies that students have experience in using the Internet. Students also access the Internet on a daily basis as shown by 69 percent (176) of the students. However, the majority of students do not shop online (87\%). The findings support those of other researchers (Jordaan \& Ehlers, 2009:31; Gupta, Handa and Gupta, 2008:437; Gupta, Handa \& Bharat, 2008:437; Van der Heijden, Verhagen \& Creemers, 2001:4) who posited that a relatively small percentage of Generation $Y$ consumers shop online, and that those that shop online, did so for small value items(Gupta, Handa \& Gupta, 2008).

Table 2 presents the mean scores of student's responses to the factors affecting online shopping. The factors are arranged in the order of their importance to students. The most appealing factors are "I can order products from distant places' and 'online shopping saves time driving from store to store' with the mean scores of 4.42 and 4.31 respectively. The 'I can order products from distant places' was rated the most appealing factor by both the online and non-online shoppers. However, online shoppers and non-online shoppers differed in the second most appealing factor. Online shoppers rated 'it provides easy access to information' as the second most appealing factor while the non-online shoppers rating 'online shopping saves time driving from store to store' which was also rated by all students as the second most appealing factor. Students were concerned that they have to wait for goods to be delivered which is a major concern for both online shoppers and non-online shoppers. 'I often consider shopping online' received the lowest scores of 2.59 from the non-online shoppers, which show that non-online shoppers do not consider shopping online. This is despite the fact that the majority of students including online and non-online shoppers access the Internet on a daily basis. 
Table 2: Factors Affecting Online Shopping Mean Scores

\begin{tabular}{|l|c|c|c|c|}
\hline Online shopping factors & N & $\begin{array}{c}\text { M (All } \\
\text { students) }\end{array}$ & $\begin{array}{c}\text { M Online } \\
\text { shoppers }\end{array}$ & $\begin{array}{c}\text { M Non-online } \\
\text { shoppers }\end{array}$ \\
\hline I can order products from distant places & 257 & 4.42 & 4.61 & 4.39 \\
\hline Online shopping saves time driving from store to store & 257 & 4.31 & 4.42 & 4.30 \\
\hline I have to wait for goods to be delivered & 257 & 4.16 & 4.23 & 4.15 \\
\hline I can purchase products at any time of the day & 257 & 4.12 & 4.32 & 4.10 \\
\hline It provides easy access to information & 257 & 3.95 & 4.55 & 3.87 \\
\hline It can be difficult to return the defective product & 257 & 3.89 & 3.94 & 3.89 \\
\hline Quality of products delivered may not be the same as one ordered & 257 & 3.85 & 3.84 & 3.85 \\
\hline My credit card information may be stolen & 257 & 3.69 & 3.48 & 3.72 \\
\hline Online shopping makes it easy to compare various products and brands & 257 & 3.62 & 3.81 & 3.29 \\
\hline My personal information may not be safe when shopping online & 257 & 3.61 & 3.61 & 3.61 \\
\hline I can find greater variety of products and models online & 257 & 3.57 & 4.19 & 3.49 \\
\hline I think Internet shopping requires less effort on my part & 257 & 3.55 & 3.77 & 3.52 \\
\hline Online shopping can enable me to do my shopping quickly & 257 & 3.43 & 3.84 & 3.37 \\
\hline I will use online shopping in future & 257 & 3.42 & 4.10 & 3.32 \\
\hline I think online shopping is easy to use & 257 & 3.37 & 3.61 & 3.34 \\
\hline Online shopping is a good idea & 264 & 3.36 & 3.87 & 3.27 \\
\hline I think I can shop online without any need for assistance & 257 & 3.36 & 3.71 & 3.31 \\
\hline I am interested in shopping online & 257 & 3.05 & 3.87 & 2.94 \\
\hline I can make better purchase decisions with online shopping & 257 & 3.02 & 3.55 & 2.94 \\
\hline I can get better prices & 257 & 2.88 & 3.00 & 2.86 \\
\hline I think I can shop online without encountering any problems & 257 & 2.79 & 2.97 & 2.77 \\
\hline I often consider shopping online & 257 & 2.70 & 3.48 & 2.59 \\
\hline
\end{tabular}

1=strongly disagree, 5=strongly agree

\subsection{Factor analysis}

The factor analysis for the factors affecting student's attitude towards online buying was conducted. The purpose of factor analysis is to condense the information in a number of original variables into a smaller set of new, composite dimensions or factors, with a minimum loss of information. It allows the researcher to search and define the fundamental constructs or dimensions assumed to underlie the original variables (Hair, Black, Babin \& Anderson, 2010). Two items were dropped from the factor analysis after they loaded unsatisfactory in the initial analysis. Of the 22 items, 20 were factor analysed. As is visible from Table 3, factor analysis yielded five factors. The first factor loaded five items including 'online shopping saves times driving from store to store', 'I can order products from distant places', 'I can purchase products at any time of the day', 'online shopping enables me to do my shopping quickly' and 'online shopping is a good idea'. The factor was named convenience. The second factor was named perceived risk since the items loading in this factor were related closely to perceived risk and security such as 'my personal information may not be safe when shopping online', 'my credit card information may be stolen', 'I have to wait for goods to be delivered', quality of products delivered may not be the same as one delivered', and 'it can be difficult to return the defective product'.

The third factor loaded three items, which measured the intention to shop online. Items included 'I am interested in shopping online', 'I often consider shopping online' and 'I will use online shopping in future'. The fourth factor was labelled 'ease of use' since it was closely related to items that reflect the ease of use of online shopping. The factor loaded four items such as 'I think I can shop online without any need for assistance', 'I think online shopping requires less effort on my part', 'I think I can shop online without encountering any problems' and 'I think online shopping is easy to use'. 
Table 3: Factor analysis

\begin{tabular}{|l|c|c|c|c|c|}
\hline Factors and variable description & $\begin{array}{c}\text { Factor } \\
\text { (Convenience) }\end{array}$ & $\begin{array}{c}\text { Factor 2 } \\
\text { (Perceived } \\
\text { risk) }\end{array}$ & $\begin{array}{c}\text { Factor 3 } \\
\text { (Shopping } \\
\text { intention) }\end{array}$ & $\begin{array}{c}\text { Factor } 4 \\
\text { (ease of } \\
\text { use) }\end{array}$ & $\begin{array}{c}\text { Factor } \\
\text { (usefulness) }\end{array}$ \\
\hline Online shopping saves time driving from store to store & .834 & .090 & .074 & .085 & .071 \\
\hline I can order products from distant places & .823 & & -.055 & .068 \\
\hline I can purchase products at any time of the day & .755 & .056 & -.034 & .202 & .195 \\
\hline Online shopping enable (can) me to do my shopping quickly & .579 & & .311 & .277 & .097 \\
\hline Online shopping is a good idea & .505 & & .404 & .052 & .114 \\
\hline My credit card information may be stolen & -.065 & .856 & -.134 & & \\
\hline Quality of products delivered may not be the same as one ordered & -.056 & .767 & & -.106 & .105 \\
\hline My personal information may not be safe when shopping online & -.036 & .692 & -.238 & .098 & -.050 \\
\hline It can be difficult to return the defective product & .139 & .686 & .072 & -.173 & \\
\hline I have to wait for goods to be delivered & .225 & .581 & .125 & .135 & -.137 \\
\hline I am interested in shopping online & .067 & -.114 & .840 & .165 & .089 \\
\hline I often consider shopping online & .100 & & .804 & .156 & .119 \\
\hline I will use online shopping in future & & & .798 & .131 & .113 \\
\hline I think I can shop online without any need for assistance & .132 & .035 & .135 & .757 & .031 \\
\hline I think Internet shopping requires less effort on my part & .183 & & -.062 & .713 & .219 \\
\hline I think I can shop online without encountering any problems & .057 & -.037 & .215 & .709 & .059 \\
\hline I think online shopping is easy to use & .144 & -.076 & .220 & .645 & .163 \\
\hline I can get better prices & .196 & & & .220 & .753 \\
\hline I can find greater variety of products and models online & & -.084 & .159 & .111 & .706 \\
\hline Online shopping makes it easy to compare various products ad brands & .246 & .043 & .349 & .088 & .595 \\
\hline \% of variance explained (Total= 60.12) & 23.62 & 14.11 & 9.11 & 7.60 & 5.75 \\
\hline Factor reliability & 0.78 & 0.77 & 0.82 & 0.73 & 0.59 \\
\hline Eigenvalues & 4.725 & 2.823 & 1.824 & 1.522 & 1.1150 \\
\hline
\end{tabular}

Factors $>0.5$ were considered

The last factor, factor 5, loaded three items and was labelled usefulness, since it reflected the usefulness of online shopping. It included items such as 'online shopping makes it easy to compare various products and brands', 'I can get better prices' and 'I can find a greater variety of products and models online'.

\subsection{Hypothesis testing}

$H_{1}$ There are significant differences between online shoppers and non-online shoppers' attitudes towards online shopping

The T-test was conducted to determine if there were any significant differences among online shoppers and nononline shoppers with respect to all five factors. The significant differences were found on four factors for both the online shoppers and non-online shoppers. Significant differences were found for both the online shoppers $(M=11.45, S D=3.21)$ and non-online shoppers (M8.85, SD=3.15); $\mathrm{t}(255)=4.92, \mathrm{p}=.000$ (two-tailed) on shopping intention. Significant differences were also found on the perceived convenience factor for online shoppers ( $M=21.06, S D=3.37)$ and non-online shoppers ( $M=19.43, \mathrm{SD}=3.54$; $\mathrm{t}(255)=2.50, \mathrm{p}=.016$.

Furthermore, significant differences were found between online shoppers $(M=14.06, S D=2.48)$ and non-online shoppers $(M=12.93, S D=3.17 ; t(255)=2.27, p=.028$ on ease of use. Again, the significant differences were found among online shoppers $(M=11.00, S D=1.71)$ and non-online shoppers $(M=9.94, S D=2.43 ; t(255)=3.04, p=.004$ on the usefulness of online shopping. There were no significant differences between online shoppers and non-online shoppers on the perceived risk $(M=19.74, S D=3.92)$ and non-online shoppers $(M=18.74, S D=4.04), t(255)=2.00, p=.881$, which shows that shoppers and non-online shoppers possess different attitudes towards online shopping on shopping intention, perceived convenience, perceived ease of use and perceived usefulness . Online shoppers and non-online shoppers did not differ with regard to attitude towards risks associated with online shopping. This supports findings by Mastercard, cited in Business Day Live (2014) that SA online shoppers are concerned about the risks and security issues associated with online shopping. This could explain why fewer Generation $\mathrm{Y}$ students shop online compared to those that do not. $\mathrm{H}_{1}$ was therefore accepted. Previous studies also found significant differences between online shoppers and non-online shoppers (Yang \& Lester, 2004). 
Table 4: T-test for online shoppers and non-online shoppers factor scores

\begin{tabular}{|l|c|c|c|c|c|c|c|}
\hline Variables & \multicolumn{2}{|c|}{ Online shoppers (N=31) } & \multicolumn{2}{c|}{ Non-online shoppers (N=226) } & \multirow{2}{*}{ DF } & T & P-value \\
\hline & $\mathrm{M}$ & $\mathrm{SD}$ & $\mathrm{M}$ & $\mathrm{SD}$ & & & \\
\hline Shopping intention & 11.45 & 3.21 & 8.85 & 3.15 & 255 & 4.92 & .000 \\
\hline Convenience & 21.06 & 3.37 & 19.43 & 3.54 & 255 & 2.50 & .016 \\
\hline Perceived risk & 19.09 & 4.23 & 19.21 & 3.99 & 255 & -1.50 & .881 \\
\hline Ease of use & 14.06 & 2.48 & 12.93 & 3.17 & 255 & 2.27 & .028 \\
\hline Usefulness & 11.00 & 1.71 & 9.94 & 2.43 & 255 & 3.04 & .004 \\
\hline
\end{tabular}

$\mathrm{P}<.05$

$\mathrm{H}_{2}$ There are significant differences between the students frequency of Internet usage and the attitude towards online shopping

As can be seen in Table 5, significant difference existed between the frequency of internet usage and usefulness, $\mathrm{F}=4.16 ; 255, \mathrm{p}=.007$ and is significant at .05 level of usefulness. There were no significant differences found between the frequency of internet usage and the four factors: shopping intention $(p=.324)$, perceived risk $(p=.614)$, ease of use $(p=.445)$, and convenience $(p=.624)$ since they all have $p$-values larger than the acceptable level of $p=0.05$. Therefore $\mathrm{H}_{2}$ was accepted since the significant differences were found between the frequency of purchase and some factors influencing students' attitude towards online shopping. Kim (2004) reported that that online shoppers have a more positive attitude towards online shopping than non-online shoppers, and that the longer the students used the Internet, the more positive their attitude is towards online shopping (Xu \& Paulines, 2005:429).

Table 5: Anova results for frequency of internet usage and factors

\begin{tabular}{|c|c|c|c|c|c|c|}
\hline & & Sum of Squares & $\mathrm{df}$ & Mean Square & $\mathrm{F}$ & Sig. \\
\hline \multirow{3}{*}{ Shopping intention } & Between Groups & 37.222 & 3 & \multirow{3}{*}{$\begin{array}{l}12.407 \\
10.658\end{array}$} & \multirow{3}{*}{1.164} & \multirow{3}{*}{.324} \\
\hline & Within Groups & 2685.868 & 252 & & & \\
\hline & Total & 2723.090 & 255 & & & \\
\hline \multirow{6}{*}{ Security and risk } & Between Groups & 29.356 & 3 & \multirow{3}{*}{$\begin{array}{c}9.785 \\
16.244\end{array}$} & \multirow{3}{*}{.602} & \multirow{3}{*}{.614} \\
\hline & Within Groups & 4093.484 & 252 & & & \\
\hline & Total & 4122.840 & 255 & & & \\
\hline & Between Groups & 26.014 & 3 & \multirow{3}{*}{$\begin{array}{l}8.671 \\
9.707\end{array}$} & \multirow{3}{*}{.893} & \multirow{3}{*}{.445} \\
\hline & Within Groups & 2446.096 & 252 & & & \\
\hline & Total & 2472.109 & 255 & & & \\
\hline \multirow{3}{*}{ Usefulness } & Between Groups & 68.245 & 3 & \multirow{3}{*}{$\begin{array}{c}22.748 \\
5.461\end{array}$} & \multirow{3}{*}{4.166} & \multirow{3}{*}{.007} \\
\hline & Within Groups & 1376.193 & 252 & & & \\
\hline & Total & 1444.437 & 255 & & & \\
\hline \multirow{3}{*}{ Convenience } & Between Groups & 15.224 & 3 & \multirow{3}{*}{$\begin{array}{c}5.075 \\
12.789\end{array}$} & \multirow{3}{*}{.397} & \multirow{3}{*}{.755} \\
\hline & Within Groups & 3222.776 & 252 & & & \\
\hline & Total & 3238.000 & 255 & & & \\
\hline
\end{tabular}

$\mathrm{P}<.05$

$\mathrm{H}_{3}$ Age of students significantly influences student's attitudes towards online shopping

As shown in Table 7, the results of the Anova have proved that Generation $Y$ students across different age groups do not possess different attitudes towards online buying since all the factors had P-value larger than 0.05 . The findings are similar to those of Kim (2004:60) who found that consumers in different age groups possess similar attitudes towards online shopping. However, the findings differ from those of Khare et al., (2012:167) who found significant differences among different age groups and attitude towards online shopping. 
Table 7: Anova: age of students and factors

\begin{tabular}{|c|c|c|c|c|c|c|}
\hline & & Sum of Squares & df & Mean Square & $F$ & Sig. \\
\hline \multirow{3}{*}{ Shopping intention } & Between Groups & 18.967 & 3 & 6.322 & \multirow{3}{*}{.590} & \multirow{3}{*}{.622} \\
\hline & Within Groups & 2708.838 & 253 & \multirow[b]{2}{*}{10.707} & & \\
\hline & Total & 2727.805 & 256 & & & \\
\hline \multirow{3}{*}{ Security and risk } & Between Groups & 67.015 & 3 & \multirow{3}{*}{$\begin{array}{l}22.338 \\
16.031\end{array}$} & \multirow{3}{*}{1.393} & \multirow{3}{*}{.245} \\
\hline & Within Groups & 4055.864 & 253 & & & \\
\hline & Total & 4122.879 & 256 & & & \\
\hline \multirow{3}{*}{ Ease of use } & Between Groups & 9.147 & 3 & \multirow{3}{*}{$\begin{array}{l}3.049 \\
9.773\end{array}$} & \multirow{3}{*}{.312} & \multirow{3}{*}{.817} \\
\hline & Within Groups & 2472.448 & 253 & & & \\
\hline & Total & 2481.595 & 256 & & & \\
\hline \multirow{3}{*}{ Usefulness } & Between Groups & 19.901 & 3 & \multirow{3}{*}{$\begin{array}{l}6.634 \\
5.648\end{array}$} & \multirow{3}{*}{1.175} & \multirow{3}{*}{.320} \\
\hline & Within Groups & 1428.838 & 253 & & & \\
\hline & Total & 1448.739 & 256 & & & \\
\hline \multirow{3}{*}{ Convenience } & Between Groups & 28.720 & 3 & \multirow{3}{*}{$\begin{array}{c}9.573 \\
12.692\end{array}$} & \multirow{3}{*}{.754} & \multirow{3}{*}{.521} \\
\hline & Within Groups & 3211.163 & 253 & & & \\
\hline & Total & 3239.883 & 256 & & & \\
\hline
\end{tabular}

$\mathrm{P}<.05$

Regression analysis was computed to determine if the perceived convenience, perceived risk, perceived usefulness and perceived ease of use could be used to predict Generation $Y$ students' intention to shop online. The prediction model was statistically significant, $F(4,252)=16.611, p<0.005$. The model accounted for approximately 21 percent of the variance of shopping intention ( $R^{2}=.209$, adjusted $\left.R^{2}=.196\right)$. However, the relatively small adjusted $R^{2}$ indicates that a small portion of the variances in the independent variables were explained by the four factors: perceived convenience, perceived risk, perceived usefulness and perceived ease of use. This implies that Generation Y students could be influenced by factors other than those investigated in this study to shop online

Table 8: Regression results - intention to shop

\begin{tabular}{|c|c|c|c|c|c|c|}
\hline Mode & $\mathrm{R}^{2}$ & R squared & Adjusted R squared & Change in $\mathrm{R}^{2}$ & F change & Sig. of $\mathrm{F}$ \\
\hline 1 & .457 & .209 & .196 & .209 & 16.611 & .000 \\
\hline
\end{tabular}

\begin{tabular}{|c|l|c|c|c|c|c|}
\hline Model & Variable and coefficient & $\boldsymbol{B}$ & S.E $\boldsymbol{B}$ & Beta & $\boldsymbol{t}$. & Sig. of $\boldsymbol{F}$ \\
\hline 1 & Constant & 2.426 & 1.441 & & 1.684 & .93 \\
\hline & Perceived risk & -.092 & .046 & -.113 & -1.995 & .047 \\
\hline & Perceived convenience & .141 & .058 & .154 & 2.412 & .017 \\
\hline & Perceived usefulness & .299 & .087 & .218 & 3.447 & .001 \\
\hline & Perceived ease of use & .208 & .067 & .199 & 3.125 & .002 \\
\hline
\end{tabular}

\section{Discussion}

This research investigated the factors that determine the Generation $Y$ students' attitude towards online shopping. The findings indicated that majority of students do not shop online. However, students accessed the Internet more frequently. Furthermore, the results of the study showed that online and non-line shoppers differed significantly on the four factors; shopping intention, convenience, ease of use, and usefulness. However, online and non-online shoppers did not differ on their attitude towards perceived risk and security differences among the factors determining their attitude towards online shopping. The age of students did not influence their attitude towards online shopping.

The factor analysis produced five factors; convenience, perceived risk and security, shopping intention, ease of use, and usefulness. The convenience factor loaded five items and loaded 23.65 percent of the total variance explained. This implies that students weigh the convenience of more than other factors when considering online shopping.

The second factor, perceived risk and security loaded 14.11 of the total variance explained and loaded five factors. This is an indication that perceived risk and security are major factors influencing students' attitude towards online shopping. The shopping intention of students was identified as the third factor that determines students' attitude towards online shopping. The factor loaded 9.11 percent of the total variance explained. Despite the fact that the majority of 
students did not shop online, they have a positive attitude towards shopping online in the future. The above findings have major implications of marketers targeting the student markets for online shopping. Markets will have to consider those factors that are more important for students when shopping online and satisfy students on such factors such as convenience, perceived risk and security to influence their intention to shop online.

The ease of use factor loaded as the fourth factor and accounted for 7.60 percent of the total variance explained. Four items were loaded on this factor, therefore, implying that marketers must make sure that they make online shopping easy to use for the Generation Y student market. The last factor, which loaded three items, was named usefulness. It loaded 5.75 of the total variance explained.

\section{Concluding Remarks}

Generation $Y$ students have not embraced online shopping since the outcomes of this study showed that majority of this Generation $Y$ students did not shop online. This is despite the fact that students access the Internet more frequently on a daily basis. This contradicts the findings from other studies that students are more likely to shop online since they use the Internet frequently. However, online shopping is still in its infancy in SA compared to other countries. Therefore, online retailers could still consider factors important to Generation $Y$ students online shopping. This would be useful to persuade Generation $Y$ students to shop online as online retailers will accommodate their needs.

Consistent with prior studies, this research identified convenience as the most important dimension that influences Generation $Y$ students' online shopping behaviour. Generation $Y$ students were also influenced by the perceived security. Therefore, markets targeting Generation $Y$ students should ensure that online shops are convenient and that Generation $Y$ students' information and transactions are secure. The perceived usefulness and perceived ease of use had less impact on student's attitude towards online shopping which contradict findings by Davies (1989) that these are the two most important factors influencing attitude towards online shopping.

This research study only investigated the Generation $Y$ students in one university. The results of the study might not be generalised for black Generation $Y$ across SA. Future studies could determine reasons why the majority of students never shop online.

\section{References}

Alam, S. S., Bakar, Z., Ismail, H. B., \& Ahsan, M. N. (2008). Generation Y consumers online shopping: an empirical study. Journal of Internet Business Issue , 5,81-98.

Alch, M. L. (2000). The echo-boom generation.: a growing force in American society. Futurist, 35(5),42.

Babin, B. J., Darden, W.R., \& Griffen, M. (1994). Work and/or fun: measuring hedonic and utilitarian shopping value. Journal of Consumer Research, 20 (4),644-656.

Balasubramanian, S. (1997). Two essays in direct marketing. Ph.D. Dissertation. New Haven, CT. USA: Yale University.

Bevan-Dye, A. L., Garnett, A., \& de Klerk, N. (2012). Materialism, status consumption and consumer ethnocentrism amongst black Generation Y students in South Africa. African Journal of Business Management, 6(16), 5578-5586.

Brown, I., Cajee, Z., Davies, D., \& Stroebel, S., (2003). Cell phone banking: predictors of adoption in South Africa - an exploratory study. International Journal of Information Management, 23, 381-394.

Brown, M., Pope, N., \& Voges, K. (2003). Buying or browsing? An exploration of shopping orientations and online purchase intention. European Journal of Marketing, 37(11/12), 1666-1684.

Bigne'-Alcaniz, E., Ruiz-Mafe', C., Alda's-Manzano, J., \& Sanz-Blas, S. (2008). Influence of online shopping information dependency and innovativeness on internet shopping adoption, Online Information Review, 32(5), 648-667.

Broadbridge, A. M., Maxwell, G. A., \& Ogden, S. M. (2007). Experiences, perceptions and expectations of retail employment for Generation Y. Career Development International, 12(6), 523-544.

Business Day Live. (2014). Consumers in SA still wary of online shopping security. [online] Available: http:/lwww.bdlive.co.za/business/ retail/2014/03/27/consumers-in-sa-still-wary-of-online-shopping-security. (29 July 2014).

Cant, M. C. \& Machado.R. (2005).Marketing success stories. 5th ed. Cape Town: Oxford.

Childers, T. L., Carr, C. L., Peck, J. P., \& Carson, S. (2001). Hedonic and utilitarian motivations for online retail shopping behaviour. Journal of Retailing, 77, 511-535.

Cui, Y., Trent, E.S., Sullivan, P.P. \& Matiru, G.N. (2003). Cause-related marketing: how Generation Y responds. International journal of retail \& distribution management,31(6):310-320.

Davies, F.D. (1989). Perceived usefulness, perceived ease of use, and user acceptance of information technology. MIS Quarterly, 13(3), 319-340.

Du Plessis, P. J., Mostert, P. G., \& North, E. J. (2004). Period of Internet usage: an indicator of the buying behaviour of Internet users? SAJEMS, 7(1), 75-87.

Effective Measure. (2013). South African Online Report for June 2013. [Online] Available: www.efectivemeasure.com (22 April, 2014). 
Foscht, T., Schloffer, J., Maloles, C. \& Chia, S.L. (2009). Assessing the outcomes of Generation-Y customers' loyalty. International journal of back marketing, 27(3),218-241.

Gupta, N., Handa, M., \& Gupta, B. (2008). Young adults of India - online surfers or online shoppers. Journal of Internet Commerce, 7(4), 425-444

Ha, S., \& Stoel, L. (2009). Consumer e-shopping acceptance: antecedents in a technology acceptance model. Journal of Business Research, 62, 565-571.

Jen- Hung, H., \& Yi-Chun, Y. (2010). Gender differences in adolescents' online shopping motivations. African Journal of Business Management, 4(6), 849-857.

Johnson, K.K.P., Lennon, S.J., Jasper, C., Damhorst, M.L. and Lakner, H.B. (2003). An application of Rogers' innovation model: Use of the internet to purchase apparel, food, and home furnishing products by small community consumers, Clothing and Textiles Research Journal, 21(4),185-96.

Jordaan, Y. \& Ehlers, L. (2009). Generation Y consumers' media usage and online purchase likelihood. Journal of Family Ecology and Consumer Sciences, 27, 24-34.

Jordaan,Y., Ehlers, L., \& Grove, J.M. (2011). Advertising credibility across media channels : perceptions of Generation Y consumers. Communicare 30(1),1-20.

Kau, A. K., Tang, Y. E., \& Ghose, S. (2003). Typology of online shoppers. Journal of Consumer Marketing, 20(2), 139-156.

Khare , A., Khare, A., \& Singh, S. (2012). Attracting shoppers to shop online - challenges and opportunities for the Indian retail sector, Journal of Internet Commerce, 11:2, 161-185.

Khare, A. \& Rakesh, S. (2011). Antecedents of online shopping behaviour in India: an examination. Journal of Internet Commerce, 10(4), 227-244.

Kim, J. (2004). Understanding consumers' online shopping and purchasing behaviours. Thesis. Doctor of Philosophy. Oklahoma: Graduate College of Oklahoma State University.

Kinley, T.R., Josiam, B.M. \& Lockett, F. (2010). Shopping behaviour and the involvement construct. Journal of fashion marketing and management, 14(4),562-575.

Kotler P (2003). Marketing Management. 11th ed. Upper Saddle River, NJ, USA: Prentice Hall.

Lian, J. \& Lin, T. (2008). Effects of consumer characteristics on their acceptance of online shopping: comparisons among different product types. Computers in Human Behavior, 24(1), 48-65.

Ma, Y.J. \& Niehm, L.S. (2006). Service expectations of older Generation Y customers. Managing service quality, 16(6),620-640.

Mandlazi, L., Dhurup, M., \& Mafini, C. (2013). Generation Y consumer shopping styles: evidence from South Africa. Mediterranean Journal of Social Sciences, 4(14), 153-164.

Markert, J. (2004). Demographics of age: generational and cohort confusion. Journal of current issues and research in advertising, 26(2):11-25.

Moschis, G. P., \& Moore, R. L.(1979). Decision making among the young: a socialization perspective. Journal of Consumer research, 6(sep), 101-112.

Muller, R. (2011). Influence of colour on the consumer behaviour of Generation Y students in the Vaal Triangle. Dissertation. Masters of Commerce in Marketing Management. Vaal Triangle Campus: North-West University.

Park, C. H., \& Kim, Y. G. (2003). Identifying key factors affecting consumer purchase behaviour in online shopping context. International Journal of Retail \& Distribution Management, 31(1), 16-29.

Rahman, S. \& Azhar, S. (2010). Xpressions of Generation Y: Perceptions of the mobile phone service industry in Pakistan. Asia pacific journal of marketing \& logistics, 23(1),91-107.

Ramnarain, Y., \& Govender, K. K. (2013). The relationship among certain youths' demographic variables and their social media browsing behaviour. African Journal of Business Management, 7(25), 2495-2499

Ranganathan, C. \& Ganapathy, S. (2002). Key dimensions of business to consumer websites. Journal of Information Management, 39(6), 457-465.

Seock, Y-K., \& Chen-Yu, J.H. (2007). Website evaluation criteria among US college student consumers with different shopping orientations and internet channel usage. International Journal of Consumer Studies, 31, 204-212.

Schiffman, L.G. \& Kanuk, L.L. (2007). Consumer behaviour. 9th ed. Upper Saddle River: Pearson.

Schwalbe, B.C. (2009). Leveraging the digital media habits of the millenials: Strategies for teaching journalism courses. Journal of Southwestern Mass Communication, 25(1),53-68.

Shih, H.P. (2004). An empirical study on predicting user acceptance of e-shopping on the Web. Information and Management, 41, 351368.

Smith, T. K. (2012). Longitudinal study of digital marketing strategies targeting Millennials. Journal of Consumer Marketing, 29(2),86-92.

Sorce, P., Perotti, V., \& Widrick, S. (2005). Attitude and age differences in online buying. International Journal of Retail \& Distribution Management, 33(2), 122-132.

Statistics South Africa. 2013. Mid-year population estimates 2013. p0302.

Student Village. 2014. SA student spend repor. [Online]Available: http://www.studentmarketing.co.za/ research-sa-student-spend-report2014/sa-student-spend-report-2014-presentation (20 June 2014).

Then, N.K. \& DeLong, M.R. (1999). Apparel shopping on the web. Journal of Family and Consumer Sciences, 91(3),65-8.

Twenge, J.M. \& Cambell, S.M. (2008). Generational differences in psychological traits and their impact on the workplace. Journal of Managerial Psychology, 23(8), 862-877. 
Van der Heijden, H., Tibert Verhagen T., \& Creemers, M. (2000). Predicting online purchase behaviour: Replications and tests of competing models. Serie Research memoranda.

Vijayasarathy, L. R. (2004). Predicting consumer intentions to use online shopping: the case for an augmented technology acceptance model. Information and Management Journal, 41(2004), 747-762.

Vrechopoulos, A. P., Siomkos, G. J., \& Doukidis, G. I. (2001). Internet shopping adoption by Greek consumers. European Journal of Innovation Management, 4(3), 142-153.

Wolfinbargar, M., \& Gilly, M. G. (2001). Shopping online for freedom, control, and fun. California Management Review, 43(2), 34-55.

World Wide Worx. (2012). [Online] Available: http://www.worldwideworx.com.. (22 Pril 2014)

Xu, Y. \& Paulins, V.A. ( ). College students' attitudes toward shopping online for apparel products: Exploring a rural versus urban campus. Journal of Fashion Marketing and Management, 9(4), 420-433

Yang, B., \& Lester, D. (2004). Attitudes toward buying online. Cyber Psychology \& Behavior, 7(1), 85-91. 